\title{
TCF12 Gene
}

National Cancer Institute

\section{Source}

National Cancer Institute. TCF12 Gene. NCI Thesaurus. Code C97828.

This gene is involved in both transcriptional regulation and tissue differentiation. 